
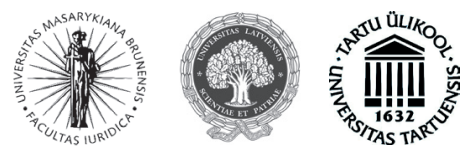

ISSN 1392-6195 (print) ISSN 2029-2058 (online) JURISPRUDENCIJA JURISPRUDENCE 2013, 20(3), p. 1113-1130.

\title{
NOTARIATO AKTUALIJOS
}

\author{
Laura Gumuliauskiené, Dalija Svirbutienè
}

Mykolo Romerio universiteto Teisès fakulteto

Civilinès justicijos institutas

Ateities g. 20, LT-08303 Vilnius, Lietuva

Telefonas (+370 5) 2714593

Elektroninis paštas laura@sgka.lt

Pateikta 2013 m. liepos 1 d., parengta spausdinti 2013 m. rugsèjo $20 \mathrm{~d}$.

doi:10.13165/JUR-13-20-3-13

Anotacija. Straipsnyje apžvelgiamos Lietuvoje nuo $1992 \mathrm{~m}$. veikiančio nepriklausomo lotyniškojo tipo notariato nüdienos aktualijos, patirtis, iššükiai bei perspektyvos Lietuvos teises kontekste, taip pat atsižvelgiant $i$ tarptautines notariato veiklos teisinio reglamentavimo tendencijas. Straipsnyje aptariamas daug diskusiju sukelęs ir Europos Sajungos Teisingumo Teisma pasiekęs pilietybès reikalavimas asmenims, norintiems tapti notarais, notaru atliekamu funkciju ivairove bei ju spektro pokyčiai skirtingose valstybèse ir laiko požiüriu, e. notaro koncepcija, notariniu paslaugu tarptautiškumo didejimas bei naujausios Europos Sajungos notary veiklos teisinio reglamentavimo iniciatyvos, notariškai patvirtintu autentišku dokumentu galiojimas.

Reikšminiai žodžiai: notaras, lotyniškasis notariatas, autentiškas dokumentas, notarinis veiksmas. 


\section{İvadas}

Notariato institucija tokia, kaip mes ją suprantame šiandien - laisva ir nepriklausoma, kurios veikla pagrịsta lotyniškojo (laisvojo) notariato principais, Lietuvoje sukurta 1992 m., priemus Lietuvos Respublikos notariato istatymą ${ }^{1}$ (toliau tekste - Notariato įstatymas). Lotynų notariatas, atliekantis valstybès numatytas viešo pobūdžio funkcijas, veikia dvidešimt dviejose Europos Sajungos valstybėse narèse ir daugiau nei aštuoniasdešimtyje pasaulio valstybių. Lotyniškojo notariato tėvyne laikoma Italija, kur $773 \mathrm{~m}$. dokumentuose atsirado sąvoka notarius publicus, reiškianti, kad šis asmuo yra viešosios valdžios patikètinis, kurio sudarytas dokumentas turi viešojo dokumento pobūdį. XI a. notarinis dokumentas igijo publica fides (viešo pasitikẻjimo) dokumento statusą ir užèmė svarbiausią vietą kitų ịrodymų atžvilgiu. Galutinai viešasis notariatas susiformavo XII a. viduryje, kai tiek valstybe, tiek bažnyčia pripažino, kad notariškai patvirtintas dokumentas yra viešasis aktas².

Notarų veikla siekiama bendrojo, viešojo intereso tikslų, o visų pirma - užtikrinti, kad civiliniuose teisiniuose santykiuose nebūtų neteisètų sandorių ir dokumentų. Lotyniškajam notariatui būdingi šie požymiai: notarai - tai savarankiška profesine veikla besiverčiantys valstybės įgalioti asmenys, kuriems dalį funkcijų perdavusi valstybẻ kontroliuoja jų vykdymą; notarai atlieka įstatymu pavestas viešąsias funkcijas; jų patvirtinti dokumentai pripažįstami viešu dokumentu, o juose įtvirtinti faktai laikomi nustatytais ir neįrodinejjami, kol šie dokumentai ar jų dalys įstatymų nustatyta tvarka nėra pripažinti negaliojančiais; notarų vykdoma veikla patenka ị prevencinio teisingumo, kuriuo užtikrinamas teisinių ir verslo santykių stabilumas, sritį; notaro patvirtinti dokumentai yra autentiški (acte authentique) ir turi didesnę ịrodomają galią (prima facie), o juos pripažinti negaliojančiais gali tik teismas ir tik ịstatyme nustatytomis sąlygomis; notarai skiriami valstybės institucijų, ribojant notarų skaičiu (numerus clausus principas), reguliuojant veiklos vietą bei nustatant notarinių veiksmų atlyginimo dydį ir t. t. Anot V. Gaivenio ${ }^{4}$, ,lotynų notariato sistemos pagrindas yra kompromisas, kurio esmè ta, kad viešosios valdžios funkcijas atlieka laisvos profesijos žmonès, esantys specialiai parengti ir atsakingi už padarytą žalą“. Lietuvos Aukščiausiasis Teismas yra išaiškinęs, kad „konkretaus notaro užduotis yra atliekamais notariniais veiksmais patikrinti tvirtinamo sandorio atitiktị įstatymams, nes notarui valstybė yra suteikusi svarbius įgaliojimus jam

1 Lietuvos Respublikos notariato ịstatymas. Valstybès žinios.1992, Nr. 28-810.

2 Plačiau žr. Gaivenis, V. Nuo raštininko iki notaro. Vilnius: R. Paknio leidykla, 2007, p. 22-23; Karpavičienè, J. Lietuvos notariato istorija. Vilnius: R. Paknio leidykla, 2012.

$32012 \mathrm{~m}$. balandžio 19 d. Lietuvos Respublikos notariato ịstatymo 3, 19, 22, 23 straipsnių pakeitimo ir İstatymo papildymo $19^{1}$ straipsniu įstatymas (Valstybès žinios. 2012, Nr. 50-2444) numato šešis pagrindinius lotyniškojo notariato tradicijomis pagrịstus notarų paslaugų ịkainių nustatymo kriterijus: 1) tvirtinimo sandorio ar kito notarinio veiksmo verté, 2) atliekamo notarinio veiksmo ar teikiamos paslaugos pobūdis, 3) notaro ekonominio nepriklausomumo užtikrinimas, 4) notaro profesinès veiklos ir civilinès atsakomybès rizika, 5) kryžminis subsidijavimas, 6) sąnaudų kriterijus.

4 Gaivenis, V. Notaras šiandienos teisinèje sistemoje. Justitia. 1999, 1-6: 15. 
vykdant viešają funkciją - apsaugoti teisètumą civiliniuose teisiniuose santykiuose, tai suponuoja ir notaro griežtos profesinės atsakomybės ypatumus ${ }^{\text {" } 5}$.

Europos Sajungos Teisingumo Teismas (toliau tekste - ESTT) savo praktikoje pripažino, kad notarų funkcijos yra viešaja teise suteikti igaliojimai valstybės interesams ginti ${ }^{6}$. Tai, kad notarams pavestos viešosios valdžios funkcijos, taip pat buvo konstatuota $1994 \mathrm{~m}$. sausio $18 \mathrm{~d}$. Europos Parlamento rezoliucijoje ir dar kartą patvirtinta 2006 m. kovo 23 d. rezoliucijoje. Europos Parlamento nuomone, notarams valstybejs perduoda viešosios valdžios funkcijas, todèl šiai profesijai taikytina valstybès tarnybos išimtis. Lietuvos Respublikos Konstitucinis Teismas (toliau tekste - Konstitucinis Teismas) 2008 m. sausio 7 d. nutarime „Dèl Lietuvos Respublikos antstolių ístatymo 45 straipsnio 3, 5 dalių atitikties Lietuvos Respublikos Konstitucijai“"7 nurodè, kad ,antstolio, kaip ir notaro, profesija - tai valstybės kontroliuojama profesija, t. y. toks viešaji interesą užtikrinančių funkcijų vykdymas, kai tai daro savarankiška profesine (privačia) veikla besiverčiantys asmenys, o jiems šias funkcijas vykdyti perdavusi valstybė turi kontroliuoti, kaip jos vykdomos“. Kitame nutarime Konstitucinis Teismas konstatavo, kad notarų funkcijų vykdymo užtikrinimas - viešasis interesas ir valstybès priedermé ${ }^{8}$.

Pagal Europos teisinę tradiciją, notaras nèra vien dokumentų tvirtintojas. Notariatas yra vienas iš pamatinių sutarčių įforminimo teisinès kultūros ,akmenų“. Pagal savo teisinị reglamentavimą ir gilias tradicijas, notaro profesija labai priartinta prie teisèjo profesijos, o tai leidžia notariatui vaidinti svarbų vaidmenị ginčų prevencijos ir reguliavimo srityje ${ }^{9}$. Notaro teikiamos teisinès konsultacijos ir dokumentų tvirtinimas atlieka ginčų prevencijos funkciją. Šiai profesijai dar priskiriama socialinès rimties ir taikos išsaugojimo funkcijos, todèl jai būtinas atitinkamas reglamentavimas ir valstybès apsauga.

\section{Pilietybès reikalavimas notarams}

Valstybė, suteikdama notarui didelius igaliojimus ir pasitikèjimo, nustato ir gan griežtus reikalavimus asmenims, norintiems tapti notarais, bei tiksliai reglamentuoja tapimo notaru procedūrą. Pirmiausia, tai pilietybės, atitinkamo teisinio išsilavinimo, nepriekaištingos reputacijos, valstybinès kalbos mokèjimo ir kiti reikalavimai.

5 Lietuvos Aukščiausiojo Teismo 2008 m. balandžio 29 d. nutartis civilinejje byloje Nr. 3K-3-264/2008.

6 ESTT byla Colegio de Oficiales de la Marina Mercante Española v. Administración del Estado Nr. C-405/01.

7 Lietuvos Respublikos Konstitucinio Teismo 2008 m. sausio 7 d. nutarimas „Dėl Lietuvos Respublikos antstolių įstatymo 45 straipsnio 3, 5 dalių atitikties Lietuvos Respublikos Konstitucijai“. Valstybès žinios. 2008, Nr. 4-136.

8 Lietuvos Respublikos Konstitucinio Teismo 2010 m. kovo 22 d. nutarimas „Dėl Lietuvos Respublikos notariato įstatymo 23 straipsnio 3 dalies (2003 m. sausio 23 d. redakcija) atitikties Lietuvos Respublikos Konstitucijai“. Valstybès žinios. 2010, Nr. 34-1620.

9 Woschnak, K. Notariatas Europos Sajungoje. Padètis Europoje: iššūkiai ir profesinès strategijos gairès. Lietuvos notariato uždaviniai Respublikai tapus Europos Sajungos nare. Tarptautinès konferencijos, vykusios 2004 m. vasario 12 d., medžiaga. Lietuvos notarų rūmai, 2004. 
Europos Komisija, prieštaraujanti diskriminacijai dèl pilietybės bei norėdama pašalinti konkurencijos teisès normų pažeidimus, susijusius su notarinių paslaugų rinkos reguliavimu Europos Sajungoje, nurode, kad Europos Bendrijos steigimo sutarties ${ }^{10}$ (toliau tekste - Europos Bendrijos sutartis) 43 straipsnis draudžia bet kokią diskriminaciją dèl pilietybès, išplaukiančią iš teisès aktų, kaip ịsisteigimo laisvès ribojimą. $2006 \mathrm{~m}$. spalio 18 d. Europos Komisija pradejjo pažeidimo procedūrą prieš Lietuvą (Nr. 2006/2234) dèl pilietybės reikalavimo taikymo notarams ${ }^{11}$. Europos Komisija pabrèžia, kad Notariato i̊statymo nuostata, įtvirtinanti, kad notaru gali tapti tik Lietuvos Respublikos pilietis, prieštarauja Europos Bendrijos steigimo sutarties nuostatoms dèl ịsisteigimo laisvès ir nèra pateisinama sutarties 45 straipsniu (dabartinis Sutarties dẻl Europos Sajungos veikimo $^{12} 51$ straipsnis) išimtimi, pagal kurią Europos Bendrijos steigimo sutarties nuostatos netaikomos veiklai, kuri bet kurioje valstybejje yra susijusi, nors ir laikinai, su viešosios valdžios funkcijų vykdymu. $2007 \mathrm{~m}$. sausio mėnesị Europos Komisijai pateiktame Lietuvos Respublikos teisingumo ministerijos (toliau tekste - Teisingumo ministerija) atsakyme buvo išdėstyti argumentai dẻl nesutikimo su Komisijos nuomone. Tačiau Komisijos nuomone, Lietuvos, kaip ir kitų valstybių, prieš kurias pradèta procedūra, teisès aktais notarams suteiktos funkcijos turi silpną ryšį su viešosios valdžios funkcijų vykdymu. 2007 m. spalio mènesị Europos Komisijos nuomonès dèl pilietybès reikalavimo taikymo sulaukè ir Čekija, Latvija, Vengrija, Malta, Lenkija, Slovakija ir Slovènija.

Po Komisijos pastabų dèl pilietybès reikalavimo notarams tokius reikalavimus panaikino Estijos Respublika, Italijos Respublika, Ispanijos Karalystè, Portugalijos Respublika.

2008 m. birželio 2 d. Lietuvos Respublikos Vyriausybė pritarẻ Lietuvos ịstojimui i ESTT nagrinejjamas bylas C-47/08 ${ }^{13}, \mathrm{C}-50 / 08^{14}, \mathrm{C}-51 / 08^{15}, \mathrm{C}-52 / 08^{16}, \mathrm{C}-53 / 08^{17}$, C-54/08 ${ }^{18}$, C-61/08 ${ }^{19}$, kuriose, palaikydama Belgijos Karalystę, Liuksemburgo Didžiają Hercogystę, Prancūzijos Respubliką, Austrijos Respubliką, Vokietijos Federacinę Respubliką ir Graikijos Respubliką, toliau laikèsi savo pozicijos dèl pilietybės reikalavimo taikymo asmenims, norintiems tapti notarais.

ESTT $2010 \mathrm{~m}$. rugsejjo mėnesị pateiktoje generalinio advokato Pedro Cruz Villalon išvadoje ${ }^{20}$ teigiama, kad nustatydamos pilietybès reikalavimą asmenims, norintiems tap-

10 Europos Bendrijos steigimo sutartis (Suvestinè redakcija). [2002] OL C 340.

11 Europos teisès departamento prie Lietuvos Respublikos teisingumo ministerijos informacija [interaktyvus]. [žiūrèta 2013-08-29] ir kitur prie el. šaltinių <http://www.etd.lt/popup2.php?m_news_id=140\&tmpl_ name $=$ m_news_print_form $>$.

12 Sutarties dèl Europos Sajungos veikimo suvestinè redakcija. [2012] OL C 326.

13 Byla Komisija prieš Belgiją Nr. C-47/08.

14 Byla Komisija prieš Prancūzija Nr. C-50/08.

15 Byla Komisija prieš Liuksemburga Nr. C-51/08.

16 Byla Komisija prieš Portugalija Nr. C-52/08.

17 Byla Komisija prieš Austrija Nr. C-53/08.

18 Byla Komisija prieš Vokietija Nr. C-54/08.

19 Byla Komisija prieš Graikiją Nr. C-61/08.

$20<\mathrm{http}$ :/curia.europa.eu/juris/document/document.jsf?text=\&docid=78700\&pageIndex $=0 \&$ doclang $=1 \mathrm{t} \&$ mode $=1$ st $\&$ dir $=\&$ occ $=$ first $\&$ part $=1 \&$ cid $=2023382>$. [žiūrèta 2013-08-29] . 
ti notarais, minètos šešios valstybės pažeidè savo ịsipareigojimus pagal Europos Bendrijos steigimo sutarti. Jo nuomone, tik ta veikla, kuri vykdoma savarankiškai, konkrečiai ir tiesiogiai susijusi su viešosios valdžios funkcijų vykdymu, gali nepatekti ị ịsisteigimo laisvès apibrèžimą. Notarai dalyvauja vykdant viešosios valdžios funkcijas, tačiau tai vyksta netiesiogiai. Komisijos tvirtinimu, notarai neturi valstybinio lygio igaliojimų, t. y. neturi sprendimo prièmimo galių ir jų sprendimai (autentiški aktai) vykdytini tik tiek, kiek šalys sutinka juos vykdyti, nes jie gali būti ginčijami teisme. Notarų veikla nèra viešosios valdžios funkcijų vykdymas, nes notarai nepriima nei bendro, nei individualaus pobūdžio teisės aktų. Skirtingai nei teisėjams, notarams perduotos teismo funkcijos nesuteikia įgaliojimo spręsti šalių konfliktus. Teisinių dokumentų rengimas, konsultavimas yra parengiamoji veikla, kuri panaši ị advokatų veiklą. Be to, notarai savo profesija verčiasi konkurencijos sąlygomis, o tai nebūdinga viešosios valdžios vykdymui. Taip pat pažymėta, kad notarai tiesiogiai ir asmeniškai savo klientams atsako už žalą.

Generalinis advokatas pabrěżè, jog prielaida, kad valstybės narès pilietis negali išreikšti teisèto lojalumo kitai valstybei narei įsipareigojimo kitaip nei pirma priimdamas jos pilietybę, tikrai neatitinka nei Europos Bendrijos sutarties 17 straipsnio, nei 18 straipsnio, nei politinių su pilietybe susijusių teisių, kylančių iš sutarčių ir Europos Sajungos pagrindinių teisių chartijos ${ }^{21}$.

2011 m. gegužès 24 d. buvo priimti ESTT sprendimai bylose C-47/08 prieš Belgijos Karalystę, C-50/08 Prancūzijos Respubliką, C-51/08 Liuksemburgo Didžiają Hercogystę, C-52/08 Portugalijos Respubliką, C-53/08 Austrijos Respubliką, C-54/08 Vokietijos Federacinę Respubliką, C-61/08 prieš Graikijos Respubliką. ESTT sprendimuose konstatavo, kad pagal Europos Bendrijos sutarties 43 straipsnị (dabartinis Sutarties dèl Europos Sajungos veikimo 49 straipsnis) valstybėms narėms draudžiama asmenims, kurie nori pasinaudoti ịsisteigimo laisve, savo teisès aktuose numatyti kitokias veiklos vykdymo sąlygas nei tos, kurios nustatytos jų pačių piliečiams. Be to, Europos Bendrijos sutarties 43 straipsniu siekiama užtikrinti kiekvienam valstybès narès piliečiui naudojimąsi tomis pačiomis kaip ir nacionalinių subjektų teisèmis ir draudžiama bet kokia iš nacionalinès teisės aktų kylanti pilietybe grindžiama diskriminacija. ESTT pripažino, kad nepakanka argumentų, kad notarų veikla būtų laikoma tiesiogiai ir konkrečiai susijusi su viešosios valdžios funkcijų vykdymu, kaip tai suprantama pagal Europos Bendrijos sutarties 45 straipsnį. Kitaip tariant, ESTT konstatavo, kad notarai savo veikloje tiesiogiai nerealizuoja valstybès iuris imperini tokia apimtimi, kuri yra būtina taikant išimtį dèl pilietybès. Tačiau ypatingą notarų atliekamą funkciją ESTT vis dèlto išskyrè, pažymėdamas, jog „notaras užtikrina, kad privačių asmenų sudaryti sandoriai būtų teisiški ir teisiškai patikimi“" Kaip pažymèjo Europos Sajungos notariatų taryba (toliau CNUE $^{22}$ ) prezidentas dr. Tilmanas Götte (2012 m., Vokietija), „ypatingas pasitikejjimas,

21 [2012] OL C 326.

22 Ang. The Council of the Notariats of the European Union (CNUE) - Europos Sajungos notariatu taryba. Tai pelno nesiekianti asociacija, ịkurta 1993 m. Jos nariais yra Europos Sajungos valstybių lotyniškojo tipo notariatai (21 Europos Sajungos valstybių notariatas ir Kroatija stebėtojos statusu). CNUE tikslas atstovauti nariams Europos Sajungos institucijose, skatinti notariatų veiklą ir paslaugų teikimą, stiprinti profesinį notariatų bendradarbiavimą, rinkti, sisteminti ir teikti notariatams aktualią tarptautinę informaci- 
kuris notarams išreiškiamas teisèje, pateisinamas tik tada, kai notaras visus piliečius konsultuoja kaip nepriklausomas ir nešališkas asmuo“23.

Taip pat reikètų paminèti, kad ESTT atmetè Liuksemburgo argumentą, susijusị su būtinybe užtikrinti liuksemburgiečių kalbos vartojimą, vykdant notaro funkcijas, pažymėdamas, kad nors valstybių narių nacionalinio savitumo išsaugojimas yra teisètas Europos Sajungos teisès sistemoje gerbiamas tikslas, Didžiosios Hercogystės nurodytą interesą vis dèlto galima veiksmingai apsaugoti ir kitomis priemonèmis, o ne bendrai kitų valstybių narių piliečiams taikomu draudimu.

CNUE laikosi nuostatos, kad notarai nèra paprasti ekonominès veiklos bendrojoje rinkoje vykdytojai, o valstybès atstovai, todèl notariatai pagrịstai reikalauja Europos Bendrijos sutarties 45 straipsnio išimties. CNUE prezidentas Rudolfas Kaindlas (2012 m., Austrija) pabrèžè, kad toks ESTT sprendimas nèra notariato pabaiga. Notaro patvirtintas dokumentas išsaugojo savo tvirtinamają ir vykdomają galią, taip pat išsaugotas notaro statusas. Prof. V. Nekrošiaus manymu ${ }^{24}$, atsižvelgiant ị tai, kad ESTT pripažino galimu notarų skaičiaus bei veiklos teritorijos ribojimą, darytina išvada, kad aptartų sprendimų prièmimas iš esmès nepakeite iki tol egzistavusios situacijos. ESTT nepaneigè lotyniškojo notariato sistemos idejos, kad notarai nèra komercinès ūkinès veikos subjektai. CNUE Generalinė asamblëja prièjo prie išvados, kad net ir panaikinus pilietybės reikalavimą, užsieniečiams, norintiems verstis notaro veikla, turès galioti ir būti taikomi tokie patys reikalavimai, kaip ir tos valstybės narès piliečiams.

Atsižvelgiant $\mathfrak{i}$ tai, kad nacionalinès pilietybès reikalavimas notarams ESTT buvo pripažintas kaip pažeidžiantis ịsisteigimo laisvę, $2011 \mathrm{~m}$. gruodžio mėnesị buvo priimtas Notariato įstatymo pakeitimas ${ }^{25}$, kuriame, be kita ko, nustatoma, kad notaru, notaro atstovu ir kandidatu ị notarus (asesoriumi) Lietuvos Respublikoje gali būti Europos Sąjungos, Europos Ekonominès Erdvès susitarimą pasirašiusios valstybès ar Šveicarijos Konfederacijos piliečiai, taip pat ịtvirtintas reikalavimas asmeniui, norinčiam tapti notaru, mokèti valstybinę, t. y. lietuvių, kalbą. Pakeitimai įsigaliojo nuo $2012 \mathrm{~m}$. sausio $6 \mathrm{~d}$.

\section{Lotyniškojo notariato ypatumai skirtingose valstybèse}

Lotyniškojo notariato veikla grindžiama valstybės funkcijų perdavimu privatiems asmenims, nustatant jiems specialius kvalifikacinius reikalavimus, leidžiant savo veikloje naudoti valstybès simbolius, pripažịstant jų išduoto dokumento autentiškumą (acte authentique), suteikiant jam didesnę ịrodomają galią (prima facie) bei užtikrinant

ją, atlikti tyrimus, rengti studijas. Lietuvos notariatas ị CNUE priimtas $2004 \mathrm{~m}$. gegužès $13 \mathrm{~d}$.

23 Götte, T. Europos Sajungos notariatų tarybos veikla, tarptautinio bendradarbiavimo nauda ir tarybos įnašas stiprinant pagrindinius lotyniškojo notariato principus. Tarptautinès konferencijos „Teisė, atsakomybė, patikimumas“, vykusios 2012 m. gruodžio 1 d., pranešimas. Notariatas. 2013,15.

24 Nekrošius, V. Lietuvos notarų rūmų, Koblenco (Vokietija) notarų rūmų ir Nacionalinio muziejaus Lietuvos Didžiosios Kunigaikštystės valdovų rūmų kolokviumo „Notariatas ir viešasis interesas“, vykusio 2011 m. lapkričio 28 d. Vilniuje, pranešimo tezès. Notariatas. 2012, 13.

25 Lietuvos Respublikos notariato įstatymo 3, 15(1), 22, 23, 36, 56 straipsnių pakeitimo ir papildymo įstatymas. Valstybès žinios. 2012, Nr. 4-114. 
jo vykdymą. Kiekvieno nacionalinio notariato organizacinę struktūrą, veiklos ribas ir kompetenciją nustato nacionaliniai teisės aktai, tačiau visose valstybėse išsaugomi pagrindiniai lotyniškojo notariato veiklos ir organizaciniai principai: nepriklausomumas, nešališkumas, asmeninė atsakomybẻ klientams, paslapties išsaugojimas, kliento laisvė rinktis notarą ir t. t. Visose lotyniškojo notariato tipo valstybèse notaras turi išimtines funkcijas tam tikrais klausimais bei negali atlikti veiksmų užsienyje. Šio tipo notarams suteikiamos monopolinès teisės, tačiau šios teisès derinamos su notaro pareiga teikti paslaugas visiems, kas jų paprašo, ir jiems neleidžiama specializuotis. Notarų skaičius yra ribojamas (išskyrus Olandiją, Maltą, Rumuniją, Lenkiją, tačiau ir šiose valstybėse nèra visiškos notaro ịsisteigimo laisvès), nustatoma jų veiklos teritorija. Lietuvoje notarų skaičių ${ }^{26}$, jų buveinę ir veiklos teritoriją nustato Lietuvos Respublikos teisingumo ministras, vadovaudamasis Notarų gyventojams teikiamų teisinių paslaugų poreikių vertinimo metodika ${ }^{27}$.

Priklausomai nuo nacionalinio ịstatymų leidejjo pasirinkimo, lotyniškojo tipo notaras gali verstis vien notarine praktika (Lietuva, Lenkija, Latvija ir kt.), ir toks modelis vadinamas ,tik notaro“ modeliu, arba dirbti ir advokatūros srityje (Vokietija, Gvatemala), ir toks modelis vadinamas ,notaro-advokato“. Konkretaus modelio parinkimą lemia tos valstybės ịstatymų leidejjo pasirinkimas, atsižvelgiant ị valstybės režimą, teisinę santvarką ir tradicijas, visuomeninių teisinių santykių išsivystymo lygị, civilinės apyvartos apimtis bei kitus reikšmingus valstybejje egzistuojančius politinius, teisinius, ekonominius, socialinius faktorius.

Daugelyje valstybių notaro pareigos užimamos viešo konkurso būdu (Vokietija, Latvija, Lietuva, Estija, Italija ir kt.), tačiau, pavyzdžiui, Olandijoje notarus iki gyvos galvos skiria monarchas. Be jau minèto pilietybès reikalavimo, lotyniškojo tipo notariatai numato ir kitus reikalavimus asmenims, norintiems tapti notarais. Pavyzdžiui, Olandijoje asmuo, norintis tapti kandidatu ị notarus, turi turèti aukštajị universitetinị išsilavinimą, išlaikyti kvalifikacinį egzaminą, atlikti šešerių metų praktiką; Kanados Kvebeko provincijoje kandidatai i notarus turi turèti vadinamaji LL.L ${ }^{28}$, LL.B ${ }^{29}$ arba B.C.L ${ }^{30}$ ir papildomai privalomi vieneri metai praktinių studijų, susijusių su notarų specializacijos sritimis; Kinijoje konkretaus išsilavinimo reikalavimo nèra, tačiau pretendentas į notarus turi ne mažiau kaip dvejus metus dirbti notaro biure praktikantu ir išlaikyti Nacionalinio Teismo egzaminą. Vienas iš būdų notaru tapti Lietuvoje - tai visų pirma turèti aukštajị universitetinị teisinị išsilavinimą, ne mažiau kaip vienerius metus būti kandidatu ị notarus (asesoriumi), išlaikyti notaro kvalifikacinị egzaminą (Notariato ịstatymo 3 straipsnis).

26 Šiuo metu Lietuvoje 230 biurų profesinę veiklą vykdo 269 notarai, Estijoje - 100 notarų, Vokietijoje 9500 notarų, Latvijoje - 117 notarų, Olandijoje - 1433 notarai, Austrijoje - 822 notarai. Iki notariato reformos $1991 \mathrm{~m}$. sausio $1 \mathrm{~d}$. Lietuvoje 53 notarinėse kontorose dirbo 129 notarai. $2012 \mathrm{~m}$. Lietuvos notarai atliko apie 1,5 milijono notarinių veiksmų.

27 Patvirtinta Lietuvos Respublikos teisingumo ministro 2006 m. gruodžio 28 d. įsakymu Nr. 1R-481. Valstybés žinios. 2007, Nr. 2-94.

28 Latin Legum Licentiatus, Licentiate of Laws - Ontario universiteto suteikiamas mokslo laipsnis.

29 Bachelor of Laws - Kvebeko bendrosios teisès bakalauro laipsnis.

30 Bachelor of Civil Law - Kvebeko civilinès teisès bakalauro laipsnis. 
Notaras konkrečiose valstybėse gali turèti skirtingą statusą, pavyzdžiui, Portugalijoje, Ukrainoje notaras gali turèti dvigubą statusą - viešas pareigūnas arba privatus asmuo, Rusijos Federacijoje notaras gali būti arba valstybės pareigūnas, arba privatus darbuotojas, kontroliuojamas valstybinès institucijos ${ }^{31}$.

Tarptautinès notariato sajungos (toliau - UINL ${ }^{32}$ ) asamblejoje, vykusioje Kolumbijoje 2011 m. gruodžio 20 d., pažymèta, kad nepaisant kontinentinių skirtumų, notariatų tikslai ir uždaviniai lieka tie patys. XXI a. notaras turi būti profesionalus, modernus, lankstus, atviras visuomenei, besilaikantis profesinès etikos. Itvairiose šalyse notaru kompetencija keičiasi - vienose valstybėse ji plečiasi, kitose, atvirkščiai, - siaurèja. Pavyzdžiui, Afrikos žemyne, pagrindinės notaro veiklos sritys yra patariamoji, taikinamoji ir pasitikejjimo. Atsirado naujos funkcijos pinigų plovimo prevencijos srityje, saugios teisinių aktų judèjimo erdvės kūrime, po truputị rengiamas testamentų registras. Alžyre aktyiai dirbama ịmonių teisès srityje. Tik vienintelis Maroko notariatas gavo teisę tvirtinti kooperatinių bendrovių dokumentus, o, pavyzdžiui, Mauritanijoje visos sutartys, net automobilių perleidimo, turi būti patvirtintos notaro. Amerikos kontinente notarai atlieka klasikines ir naujas funkcijas. Naujos funkcijos atsirado kovos su pinigų plovimu ir nusikalstamumo prevencijos srityje. Notaras sprendžia ginčus kaip arbitras arba mediatorius. Notarų patvirtinti dokumentai yra pripažistami visose valstybinėse institucijose, modernizuojami viešieji registrai. Japonijoje notaro statusas šiek tiek skiriasi nuo kitu valstybių notarų. Čia valstybė notarams skiria kompensaciją už atliktą veiklą. Notarai biurus steigia savarankiškai, o jų veiklą prižiūri Teisingumo ministerija. Kinijoje notarų biurai yra dvejopo pobūdžio: steigiami Teisingumo ministerijos ir steigiami paties notaro iniciatyva. Notarai turi valstybès ịgalioto asmens statusą. Europoje viena pagrindinių notariato veiklos modernizavimo krypčių yra informacinių technologijų plètra, naujų funkcijų priskyrimas notarams. Išskirtinis notariato vaidmuo yra ekonomikos saugumo užtikrinimo srityje, dokumentų judèjimo kontrolè, nusikalstamos veikos prevencija.

UINL metinejje ataskaitoje, atlikus studijas 32 valstybėse apie notarų kompetenciją, pažymèta, kad notarai atlieka 63 skirtingas funkcijas. Klasikinėms priskiriamos šios:

- nekilnojamo turto perleidimo sutarčių tvirtinimas (visose valstybėse, išskyrus Čekiją);

- hipotekos sandorių tvirtinimas (visose valstybèse, išskyrus Čekiją);

- vedybų sutarčių tvirtinimas (visose valstybėse, išskyrus Bulgariją, Portugaliją, Rumuniją, Sloveniją);

31 Report on European Judicial Systems [interaktyvus]. [žiūrèta 2013-08-29]. <Edition2008//http://wcd.coc. int/ViewDoc.jsp?id=1336209\# p18881_486910>.

32 Pranc. Union Internationale du Notariat - Tarptautinè notariato sajunga, ịkurta $1948 \mathrm{~m}$. spalio 2 d. Tai nevyriausybinè organizacija, vienijanti 83 Europos, Amerikos, Afrikos ir Azijos valstybes (apima per 300000 notarų), kurių notariatai priklauso lotyniškojo notariato sistemai, pagrịstai romanų-germanų teisès tradicija. Tarptautinè notariato sajunga siekia viešinti ir skleisti notarinę veiklą, koordinuoti ir plètoti ją tarptautiniu mastu, atstovauti notarams tarptautinėse organizacijose, bendradarbiauti su valstybių narių ir ne narių notarų rūmais lotynų notariato vystymo klausimais, siekdama savo tikslų sprendžia strateginius tarptautinio notariato klausimus, organizuoja profesinius kongresus, mokslinę notariato veiklą ir t. t. Lietuvos notariatas į Sajungą priimtas $1994 \mathrm{~m}$. vasario $11 \mathrm{~d}$. 
- juridinių asmenų steigimo dokumentų tvirtinimas (visose valstybėse, išskyrus Bulgariją, Portugaliją, Latviją);

- testamentų tvirtinimas;

- pinigų, vertybinių popierių prièmimas ị depozitą;

- paveldejjimo klausimų sprendimas;

- dovanojimo sandorių tvirtinimas ir t. t. ${ }^{33}$

Prie naujų notarų funkcijų priskiriamos teisių registravimo, mediacijos funkcijos, taikos sutarčių, skyrybų (nesant ginčo) tvirtinimas ir t. t. Nyderlandų notarai taip pat dalyvauja santuokos nutraukimo bylose - notaras gali parengti ir pateikti teismui skyrybu prašymą, taip pat gali atstovauti šalims teisme; Vengrijoje notarai šalių sutarimu nutraukia santuokas; Estijos notarai tvirtina santuokų sudarymą ir nutraukimą; Rumunijoje notarai tvirtina santuokos nutraukimą, jei nèra nepilnamečių vaikų; Rusijos notarai tvirtina sutartis dèl ịvaikinimo; Austrijoje ir Slovėnijoje notarams suteikta teisé atstovauti klientams teisme ne ginčo teisenoje; Lietuvos notarai perėmè hipotekos registravimo funkciją, pradejjo daryti vykdomuosius ịrašus dèl priverstinio skolos išieškojimo, nuo 2012 m. pabaigos tvirtina liudytojų civilinėse bylose parodymus; Austrijoje, Belgijoje, Slovėnijoje Olandijoje, Prancūzijoje yra specialūs ịstatymai, ịteisinantys notaro kaip mediatoriaus veiklą.

Lietuvos notarai mediaciją vykdo de facto, tačiau mediacija de facto, ir mediacija kaip savarankiška funkcija yra skirtingi dalykai. Notariato įstatymas draudžia notarui užsiimti kita veikla, išskyrus pedagoginę ir kūrybinę veiklą. Lietuvos notarų rūmai palankiai vertina CNUE iniciatyvą perduoti notarams mediatoriaus funkciją. Atsižvelgdami ị Europos notarų praktiką sprendžiant ginčus neteisminiu būdu, kai notarai veikia ne tik kaip mediatoriai, bet ir kaip arbitrai (Vokietijoje, Estijoje, Austrijoje), Lietuvos notarų rūmai yra svarstę ir Prekybos arbitražo teismo steigimo galimybes. Manoma, kad šio teismo arbitrų sąraše galètų būti ir notarai. Deja, archyvuose nugulè įstatymų projektai, kuriuose buvo numatyta Lietuvoje notarams perduoti santuokos ne ginčo tvarka nutraukimo bylas, santuokos tvirtinimą, tėvų sutartis dèl vaikų išlaikymo (kaip tai numatyta Vokietijoje).

Be naujų funkcijų notarams priskyrimo, pastebimas ir priešingas reiškinys. $2008 \mathrm{~m}$. Europos Komisija pateike pasiūlymą dèl Tarybos reglamento dèl Europos privačios bendrovès statuto ${ }^{34}$. Tai turètų būti atsvara nacionalinèms ribotos atsakomybès bendrovėms. Savo pateiktame projekte Europos Komisija aiškiai atsisakè preventyvios notaro atliekamos teisinès kontrolès ir reikalavimų išlaikyti reikalaujamą formą. Bendrovès steigiamos nedalyvaujant notarui, naudojant pavyzdinius ịstatus. Nuo $2009 \mathrm{~m}$. Lietuvoj įtvirtinta galimybė individualią įmonę ar uždarają akcinę bendrovę steigti, neatliekant notarinio teisinio tyrimo, jei dokumentai registruojami tiesiogiai elektroniniu būdu, steigimo dokumentai rengiami vadovaujantis Lietuvos Respublikos Vyriausybės pa-

33 Tarptautinès lotyniškojo notariato sajungos (UINL) Europos reikalų komisijos (CAE) plenarinès sesijos, vykusios $2010 \mathrm{~m}$. gegužès 21-22 d., medžiaga (nepublikuota).

$34 \operatorname{KOM}(2008) 396$ galutinis [interaktyvus]. [žiūreta 2013-08-29]. <http://eur-lex.europa.eu/LexUriServ/ LexUriServ.do?uri=COM:2008:0396:FIN:LT:PDF>. 
tvirtintais pavyzdiniais steigimo dokumentais ${ }^{35}$. Nuo $2011 \mathrm{~m}$. Juridinių asmenų registro nuostatuose $^{36}$ atsisakyta notaro teisinio tyrimo ir steigiant asociaciją ar viešają įstaigą ${ }^{37}$.

\subsection{E. notaras}

Notaru įžengimas į elektroninę erdvę yra dėsningas ir neišvengiamas. CNUE, bendradarbiaudama su Europos Komisija, igyvendina kelis projektus, susijusius su profesinès informacijos mainais ir notarų paslaugų prieinamumo viešinimu; kuriama e. notaro sistema, kurios tikslas - automatizuojant notarų veiklos procesus, perkelti i elektroninę erdvę teikiamas notarų paslaugas, kurios būtų prieinamos tiek fiziniams, tiek juridiniams asmenims ir valstybės institucijoms. Numatoma sudaryti galimybę vienus notarinius veiksmus atlikti perkèlimo ị elektroninę erdvę 3 brandos lygiu, t. y. kai klientas paslaugos užsakymą, dokumentų pateikimą notarui gali atlikti elektroniniu būdu, tačiau rezultatą gauna atvykęs ị notaro biurą, o kitus notarinius veiksmus atlikti 4 brandos lygiu, t. y. tiek paslaugos užsakymas, tiek dokumentų pateikimas notarui, tiek notarinio veiksmo atlikimas bei notarinio dokumento pateikimas klientui būtų atliekamas elektroniniu būdu. Iggyvendinus ši projektą būtų sukurta ir perkelta ị elektroninę erdvę apie 28 šiuo metu notaru teikiamos paslaugos. E. notaro sistemoje 4 brandos lygiu numatoma atlikti tokius notarinius veiksmus: juridinių asmenų steigimo ir steigimo dokumentų pakeitimo atlikimas, paveldèjimo teisès liudijimų išdavimas, nuosavybès teisès ị dalị bendro sutuoktinių turto liudijimų išdavimas, dokumentų dublikatų išdavimas, vekselių ir čekių protestavimas ir t. t.

Estijoje jau kelerius metus veikia e. notaro sistema, leidžianti steigti juridinius asmenis; Austrija jau daugiau nei dešimtmetị naudojasi elektroniniu notarų dokumentų archyvu cyberDOC. Kartu su Valstybès įmone Registrų centru nuo 2009 m. Lietuvos notarų biuruose įdiegta ir veikia Nekilnojamojo turto sandorių viešoji elektroninė paslauga (NETSVEP) ${ }^{38}$, šiuo metu baigiami projektavimo ir konstravimo kuriamos Juridinių asmenų registravimo elektroninès paslaugos (JAREP) sistemos darbai. Su Centrine hipotekos įstaiga notarai sąveikauja per Hipotekos ir ịkeitimo sudarymo ir registravimo paslaugos (HISREP) sistemą ${ }^{39}$. Artimiausias Lietuvos notariato tikslas - sukurti elektroninę notaro knygą bei integruoti ją su elektroniškai atliekama paslauga.

35 Lietuvos Respublikos Vyriausybès nutarimas Nr. 1441 „Dèl Lietuvos Respublikos Vyriausybès 2003 m. lapkričio 12 d. nutarimo Nr. 1407 „Dèl Juridinių asmenų registro įsteigimo ir Juridinių asmenų registro nuostatų patvirtinimo“ pakeitimo“. Valstybès žinios. 2009, Nr. 135-5882.

36 Patvirtinta Lietuvos Respublikos Vyriausybès 2003 m. lapkričio 12 d. nutarimu Nr. 1407. Valstybès žinios. 2003, Nr. 107-4810.

37 Lietuvos Respublikos Vyriausybès nutarimas Nr. 701 „Dèl Lietuvos Respublikos Vyriausybès 2003 m. lapkričio 12 d. nutarimo Nr. 1407 „Dèl Juridinių asmenų registro ịsteigimo ir Juridinių asmenų registro nuostatų patvirtinimo" pakeitimo“". Valstybès žinios. 2011, Nr. 75-3612.

38 NETSVEP - nekilnojamojo turto sandorių viešoji elektroninė paslauga, kai nekilnojamojo turto registro ir kadastro informacija elektroninėmis priemonemis tiesiogiai yra teikiama notarams notaro biure. NETSVEP tikslas - supaprastinti nekilnojamojo turto sandorių sudarymo procedūras, visus reikiamus sandoriui sudaryti bei teisèms įregistruoti veiksmus atliekant pas notarą (vieno langelio principas).

39 Hipotekos ir ịkeitimo sandorị patvirtinęs notaras elektroniniu būdu perduoda hipotekos registrui duomenis hipotekai registruoti, nelieka papildomo teisminio tyrimo. Hipotekos kreditorius dèl skolos išieškojimo turi kreiptis ị notarą dèl vykdomojo ịrašo atlikimo. 
Nepaisant to, kad ị elektroninę erdvę perkeliama vis daugiau notarinių veiksmų, tačiau turi išlikti ir tiesioginis notaro ir kliento ryšys bei notaro tvirtinamo dokumento teisinè kontrolè, o e. notaras jokiu būdu neturi reikšti notariškai patvirtinto dokumento (sandorio) teisinio patikimumo sumažèjimo.

\subsection{Naujos iniciatyvos}

2010 m. pabaigoje Europos Komisija paskelbė žaliają knygą „Mažiau administracinių formalumų piliečiams. Skatinti laisvą viešųjų dokumentų judëjimą ir civilinès būklès dokumentų pasekmių pripažinimą ${ }^{640}$. CNUE darbo grupès nuomone, automatiškai galètų būti pripažįstami tik objektyvūs civilinès būklès aktai, dẻl kurių juridinio ịtvirtinimo neturètų kilti teisinių diskusijų, t. y. gimimo ir mirties faktai. Siūloma suvienodinti tarptautinès privatinès teisès normas. Be to, siūloma suteikti piliečiams galimybę pasirinkti jų teisiniam statusui taikytiną teisę.

CNUE narių nuomonès dèl pateikto projekto išsiskyrè. Prancūzijos notarų rūmai siūlo visus civilinès būklès aktų įrašus automatiškai pripažinti kitose Europos Sajungos valstybėse narése; Nyderlandų notarai mano, kad neturètų būti atsisakoma dokumentų legalizavimo (tvirtinimo pažyma Apostille) dẻl galimo sukčiavimo ir dokumentų klastojimo; Austrijos notarai siūlo kompromisinę poziciją, t. y. išplèsti automatiškai pripažistamų dokumentų sąrašą (gimimas, mirtis, pavardè, tèvystė), o sutartinị pobūdị turintiems aktams (santuoka, partnerystė) laisvą judèjimą lengvinti, vienodinant tarptautinès privatinès teisès normas ${ }^{41}$.

2011 m. pabaigoje Europos Komisija pateikè Pasiūlymą dẻl Europos Parlamento ir Tarybos reglamento dèl bendrosios Europos pirkimo-pardavimo sutarčių teisès ${ }^{42}$. Siūloma parengti bendrą Europos pirkimo-pardavimo sutarčių teisę, kuri kiekvienos valstybès narès nacionalinèje teisèje sudarytų antrą sutarčių teisès sistemą. Bendra Europos Sajungos teisè, kaip alternatyva, daugiausia būtų taikoma pirkimo-pardavimo sandoriams, sudaromiems tarp skirtingose valstybėse įsikūrusių įmonių ar pirkèjo ir pardavèjo. Diskutuojama, kokią įtaką bendra teisè turès nacionalinei teisei, ar ji galès būti taikoma vienoje valstybèje sudaromiems sandoriams, koks bus šios teisès santykis su kitais teisès aktais, kaip tai realiai paveiks verslą, kaip bus igyvendintas teisinio tikrumo principas, o kartu - ir prevencinè notaro kontrolès funkcija.

$40 \operatorname{KOM}(2010) 747$ galutinis [interaktyvus]. [žiūrèta 2013-08-29]. <http://eur-lex.europa.eu/LexUriServ/ LexUriServ.do?uri=COM:2010:0747:FIN:LT:PDF>.

$412010 \mathrm{~m}$. sausio 29 d. Lietuvoje ịsigaliojo $1976 \mathrm{~m}$. Konvencija dèl išrašų iš civilinès būklès aktu ịrašų išdavimo ịvairiomis kalbomis. Lietuvai tapus šios konvencijos dalyve, suinteresuotų asmenų išrašai iš civilinės būklès aktų, patvirtinančių gimimą, santuoką ar mirtị, kiekvienos valstybės Konvencijos dalyvès išduodami pagal konvencijoje patvirtintas formas ir kiekvienos valstybès priimami be legalizavimo ar jam lygiaverčių formalumų.

$42 \operatorname{KOM}(2011) 635$ galutinis [interaktyvus]. [žiūreta 2013-08-29]. <http://eur-lex.europa.eu/LexUriServ/ LexUriServ.do?uri=COM:2011:0635:FIN:lt:PDF>. 
$2011 \mathrm{~m}$. liepos mėnesị Europos žemės registrų asociacija (toliau - ELRA ${ }^{43}$ ) pakvietè CNUE dalyvauti europiniame „Sandorių be sienų“ (toliau - CROBECO ${ }^{44}$ ) ir „Nekilnojamojo turto registracijos be sienų“ (toliau - CRORELA ${ }^{45}$ ) projektuose. Śių sistemų esmė - sudaryti užsienio šalių asmenims galimybę parengti nekilnojamojo turto pardavimo sutartis, vadovaujantis teisès aktais tos šalies, kurioje yra nekilnojamasis turtas, ir persiųsti šias sutartis elektroniniu būdu atsakingam turto registrui, taip pat sudaryti galimybę asmenims, turintiems užsienio valstybẻje išduotą paveldèjimo teisės liudijimą i nekilnojamajị turtą, elektroniniu būdu šį liudijimą registruoti nacionalinių aktų nustatytą tvarka. Ispanijos notariatas pasiūle alternatyvų projektą „Nekilnojamojo turto sandorių palengvinimas Europoje“ (toliau - EUFides ${ }^{46}$ ), kuriam pritarè visi notariatai. Jo esmé pasinaudoti jau veikiančiomis nacionalinėmis elektroninėmis sistemomis, naudojant dvigubą e. parašą. Bendradarbiaujant šalies, kurioje yra nekilnojamasis turtas, notarui su kolega, dirbančiu toje šalyje, kurioje yra pirkejjas / pardavejas, sandorio šalims būtų pateikiama esminè su nekilnojamojo turto sandoriu susijusi informacija. Šioje procedūroje pradejjus taikyti elektronines priemones, notaras galètų greičiau parengti pirkimopardavimo sandorị ir sékmingai užbaigti procedūrą. Tačiau tai būtų tvarkoma garantuojant teisini patikimumą ir nereikalaujant, kad būtų derinamos nacionalinių daiktinès ir kadastro teisių nuostatos. Projektas remiasi galiojančia lex rei sitae.

\section{Notariatu tarptautinis bendradarbiavimas ir mokymas}

2007 m. CNUE, atlikusi savo narių notariatų nacionalinių deontologijos taisyklių analizę, nusprendè bendras taisykles susisteminti ir įtvirtinti Europos notarų elgesio kodekse, be kita ko, numatant, kad CNUE notariatai nariai bendradarbiauja ir keičiasi patirtimi, o notaras, tvirtindamas tarptautinio pobūdžio sandorị, gali kreiptis ị kitos valstybès notarą per CNUE administruojamą Europos notarų tinklą (toliau - $\mathrm{ENN}^{47}$ ). Kiekvienas ENN narys yra paskyręs savo atstovą, atsakingą už savo valstybės notarų gaunamų paklausimų persiuntimą. Šiam tikslui nuo 2009 m. veikia internetinè ENN atstovų paklausimų programa (angl. ENN Online form), kuria persiunčiami paklausimai. Joje taip pat sisteminami gauti atsakymai, kaupiama statistika. 2009-2011 m. per ENN

43 Ang. European Land Registry Association - Europos žemės registrų asociacija. Tai tarptautinè ne pelno siekianti organizacija. Pagrindinis asociacijos tikslas - žemės registravimo svarbos nekilnojamojo turto ir kapitalo rinkoje suvokimas ir didinimas.

44 Ang. Cross Border Electronic Conveyancing Conference - Tarptautinio elektroninio nuosavybės perleidimo konferencija.

45 Ang. Cross Border Registration of the Land Registers - Nekilnojamojo turto registracijos be sienų.

46 Ang. Facilitating real estate transactions in Europe - Nekilnojamojo turto sandorių palengvinimas Europoje.

47 Angl. European Notarial Network. ENN veikia nuo 2007 m. lapkričio 1 d. ENN pagrindinis uždavinys pagreitinti teisines procedūras, su kuriomis susiduria notarai, spręsdami klausimus, susijusius su kita Europos Sajungos valstybe nare. Tai paveldèjimas, bendrovès steigimas, vedybų sutartys ar bet kuris kitas atvejis, turintis tarptautinị pobūdị. ENN, kaip ir CNUE, priklauso 21 Europos Sajungos valstybès narès notariatas ir Kroatijos notariatas. Daugiau informacijos žr. <http://www.enn-rne.eu/ >. 
buvo išsiųsti 73 Lietuvos notarų paklausimai, atsakyta ì 30 paklausimų, gautų iš kitų Europos Sajungos valstybių narių (ir / ar Kroatijos) notarų.

Europos notariatų iniciatyva $2005 \mathrm{~m}$. buvo ịkurta Europos testamentų registro tinklo asociacija (toliau - ENRWA ${ }^{48}$ ). Asociacijos veiklos tikslas - bendradarbiauti Europos teisinèje erdvèje paveldèjimo teisès srityje ir skatinti testamentų abipusi pripažinimą, palengvinti testamentų ir kitų dokumentų, patvirtintų notariškai, paiešką.

CNUE duomenimis, Europos Sajungoje kasmet pradedama apie pusę milijono tarptautinio pobūdžio paveldejimo bylų, kuriose paveldimas turtas vertintinas daugiau kaip 120 mlrd. eurų. Europos Komisija, siekdama derinti tarptautinę privatinę teisę, 2009 m. pateikè pasiūlymą dèl Europos Parlamento ir Tarybos reglamento dẻl jurisdikcijos, taikytinos teisės, teismo sprendimų ir autentiškų aktų, susijusių su paveldejjimu, pripažinimo bei vykdymo ir Europos paveldèjimo pažymėjimo pradėjimo naudoti ${ }^{49}$. Lietuvos notarų rūmai palaikè siūlomą kaip pagrindinị paskutinės gyvenamosios vietos kriterijų, pagal kuri nustatoma jurisdikcija paveldejjimo bylose bei paveldèjimui taikytina teisè. Reglamentas $^{50}$ priimtas $2012 \mathrm{~m}$. liepos $4 \mathrm{~d}$. ir visa apimtimi bus pradètas taikyti nuo 2015 m. rugpjūčio 17 d. Pagal šị reglamentą visose Europos Sajungos valstybėse narėse, išskyrus Daniją, Jungtinę Karalystę ir Airiją, bus nustatoma, kokia teise turi būti vadovaujamasi tarptautinio paveldejjimo atvejais. Europos Sajungos kolizinès teisès akte pirmą kartą be išlygų įtvirtintas lex rei sitare principas. Igyvendinus Reglamentą notaro (teismo) išduotas paveldejjimo teisès liudijimas (Europos paveldejjimo sertifikatas) bus automatiškai pripažįstamas visose Europos Sajungos valstybėse narèse ir garantuos įpèdinių pagal įstatymą ar testamentą statusą, testamentų vykdytojų ir palikimo administratorių igaliojimus.

Siekdama palengvinti Europos Sajungos notarų tarpusavio bendradarbiavimą ir keitimąsi informacija, taip pat notarų paslaugų prieinamumą visoje Europos Sajungos teritorijoje, CNUE yra sukūrusi internetinį Europos notarų katalogą (toliau - EDN ${ }^{51}$ ), kuriame skelbiami visų Europos Sajungos valstybių notarų ir jų biurų kontaktiniai duomenys.

Siekiant nuolat keistis aktualia informacija, aktyviai dalyvauti priimant naujausius Europos Sajungos teisės aktus, reglamentuojančius notariato veiklą, CNUE nuolat veikia šios darbo grupès: Europos autentiškas dokumentas, Europos sutarčių teisè, Hipotekos teisė, Mediacija, Profesinès kvalifikacijos, Kova prieš pinigų plovimą, Notarų socialinè sauga ir kt. CNUE taip pat rūpinasi notarų mokymu ir kvalifikacijos kèlimu, nuolat veikia Profesinès kvalifikacijos grupé, kuriamos įvairios internetinès programos,

48 Angl. European Network of Wills Association.

$49 \operatorname{KOM}(2009) 154$ galutinis [interaktyvus]. [žiūrèta 2013-08-29]. <http://eur-lex.europa.eu/LexUriServ/ LexUriServ.do?uri=COM:2009:0154:FIN:LT:PDF>.

502012 m. liepos 4 d. Europos Parlamento ir Tarybos reglamentas (ES) Nr. 650/2012 dèl jurisdikcijos, taikytinos teisès, teismo sprendimų paveldejjimo klausimais pripažinimo ir vykdymo bei autentiškų dokumentų paveldèjimo klausimais prièmimo ir vykdymo bei dẻl Europos paveldèjimo pažymėjimo sukūrimo. [2012] OL L 201.

51 Angl. European Directory of Notaries. Daugiau informacijos žr. <www.notaries-directory.eu>. 
pavyzdžiui, Forumas teisiniams mokymams, Europos notarų akademija, Tarptautinis notarinių tyrimų institutas.

UINL yra pateiktas pasiūlymas dèl pasaulinio notarų - ekspertų tinklo sukūrimo. Siūloma, jog jais galètų būti neseniai ị pensiją išèję notarai, kurie galètų dirbti kaip ekspertai, pavyzdžiui, Pasaulio banko ar kitų organizacijų užsakymu. UINL mastu notarų kvalifikacija rūpinasi kontinentinès ir tarptautinès komisijos: Nuolatinis notarų mainų biuras, Tarptautinio notarų bendradarbiavimo komisija, Patariamoji komisija, Notarų profesinès etikos komisija ir kt.; taip pat darbo grupès: Notarinis dokumento tvirtinimas, Notarų tinklas ir notariniai dokumentai, kt.

Lietuvos notarų rūmai taip pat aktyviai bendradarbiauja su Lietuvos aukštosiomis mokyklomis $^{52}$. Bendradarbiaujant su akademine bendruomene, keičiamasi teisės žiniomis ir patirtimi, organizuojami bendri renginiai, mokslininkai skaito paskaitas notarams, universitetų studentams sudarytos galimybės atlikti mokomąją teisinę praktiką Lietuvos notarų rūmuose ir notarų biuruose.

\section{Išvados}

Notaras visada buvo ir bus ne tik konkrečiu teisinių funkcijų atlikejjas, bet ir asmuo, darantis nemažą įtaką žmonių socialinei savijautai ir teisinių santykių stabilumui.

Lotyniškojo notariato, kuriam nuo 1992 m. priklauso ir Lietuvos notariatas, tikslas - esminius šiuolaikinès visuomenès poreikius - teisinio saugumo, teisminių priemonių mažinimo, skaidrumo, tinkamos kompetencijos ir pan., atitinkančio notariato ekonominès ir socialinès naudos skleidimas.

Valstybė bendruosius poreikius atitinkančią veiklą turètų perleisti vykdyti savo kontroliuojamoms institucijoms, kurios turi būti prižiūrimos, tačiau neturi kainuoti biudžeto lěšų ir valstybė neturi būti už jas atsakinga. Tokiai veiklai priklauso ir ne ginčo teisè, todèl per notarams valstybės numatytas ir jų atliekamas funkcijas iggyvendinama viešojo ir privataus sektoriaus partneryste šiandien išgyvena atgimimą. Siekiant ir toliau gerinti viešojo ir privataus sektoriaus partnerystę, valstybė nuolat turètų persvarstyti naujų funkcijų perdavimo notarams, kaip valstybès igaliotiems asmenims, galimybes. Tai ne tik gerintų teisinių paslaugų prieinamumą visuomenei bei verslui, bet ir leistų taupyti biudžeto lěšas, atsisakant valstybei nebūdingų ir su valstybės valdymu nesusijusių paslaugų administravimo.

Ypatingai turi būti apgalvota ir paruošta pokyčio ,notaras be sienų“ tinkamo teisinio reguliavimo ir praktinio įgyvendinimo sistema. Gebejjimas veikti, peržengiant vienos šalies teisinę tvarką, yra ne tik vienas aktualiausių šiuolaikinio notariato uždavinių, bet ir galimybè notariatui užimti svarbią vietą kosmopolitiškoje ateities visuomenèje.

522001 m. sausio 4 d. Lietuvos notaru rūmai pasirašè bendradarbiavimo sutartị su Vilniaus universiteto Teisès fakultetu; $2003 \mathrm{~m}$. sausio $28 \mathrm{~d}$. pasirašyta bendradarbiavimo sutartis su Lietuvos teisès universiteto (šiuo metu - Mykolo Romerio universitetas) Teisès fakultetu; $2010 \mathrm{~m}$. vasario 5 d. pasirašyta bendradarbiavimo sutartis su Vytauto Didžiojo universiteto Teisès fakultetu; 2013 m. vasario 7 d. pasirašyta bendradarbiavimo sutartis su Kazimiero Simonavičiaus universitetu. 
Atsižvelgiant ị tai, kad nacionalinès pilietybès reikalavimas notarams ESTT buvo pripažintas kaip pažeidžiantis įsisteigimo laisvę, nuo $2012 \mathrm{~m}$. sausio $6 \mathrm{~d}$. notaru, notaro atstovu ir kandidatu i notarus (asesoriumi) Lietuvoje gali tapti ne tik Lietuvos Respublikos, bet ir kitų Europos Sajungos valstybių narių, Europos ekonominès erdvės susitarimą pasirašiusios valstybès ar Šveicarijos Konfederacijos piliečiai, mokantys valstybinę lietuvių kalbą.

Viena iš būtinų prielaidų sèkmingam šiuolaikinio pažangaus notaro funkcionavimui yra operatyvus ir patikimas notarinių veiksmų atlikimo perkèlimas ị elektroninę erdvę. Tačiau nepaisant to, kad ị elektroninę erdvę perkeliama vis daugiau notarinių veiksmų, turi išlikti tiesioginis notaro ir kliento ryšys bei notaro teisinè kontrolè, o e. notaras jokiu būdu neturi reikšti notariškai tvirtinamų autentiškų dokumentų, kurie vis plačiau juda ir yra pripažįstami kitose valstybèse, teisinio patikimumo sumažèjimo.

\section{Literatūra}

ESTT byla Colegio de Oficiales de la Marina Mercante Española v Administración del Estado Nr. C-405/01.

ESTT byla Komisija prieš Belgiją Nr. C-47/08. ESTT byla Komisija prieš Prancūzija Nr. C-50/08.

ESTT byla Komisija prieš Liuksemburga Nr. C-51/08.

ESTT byla Komisija prieš Portugalija Nr. C-52/08.

ESTT byla Komisija prieš Austriją Nr. C-53/08. ESTT byla Komisija prieš Vokietija $\mathrm{Nr}$. C-54/08.

ESTT byla Komisija prieš Graikija Nr. C-61/08.

Europos Bendrijos steigimo sutartis (Suvestinè redakcija). [2002] OL C 340.

Europos Sajungos pagrindinių teisių chartija. [2012] OL C 326.

Europos Komisijos žalioji knyga „Mažiau administracinių formalumų piliečiams Skatinti laisvą viešųjų dokumentų judejjimą ir civilinès būklès dokumentų pasekmių pripažinimą“. KOM(2010) 747 galutinis [interaktyvus]. [žiūrèta 2013-08-29]. <http://eur-lex. europa.eu/LexUriServ/LexUriServ.do?uri= COM:2010:0747:FIN:LT:PDF>.

Europos Komisijos Pasiūlymas dèl Europos Parlamento ir Tarybos reglamento dèl bendrosios Europos pirkimo - pardavimo sutar- čiu teisės. KOM(2011) 635 galutinis [interaktyvus]. [žiūrèta 2013-08-29]. <http://eurlex.europa.eu/LexUriServ/LexUriServ.do?u ri=COM:2011:0635:FIN:1t:PDF>.

Europos Komisija Pasiūlymas dèl Europos Parlamento ir Tarybos reglamento dèl jurisdikcijos, taikytinos teisès, teismo sprendimų ir autentiškų aktų, susijusių su paveldejjimu, pripažinimo bei vykdymo ir Europos paveldèjimo pažyméjimo pradèjimo naudoti. $\operatorname{KOM}(2009) 154$ galutinis [interaktyvus]. [žiūrèta 2013-08-29]. <http://eur-lex.europa.eu/LexUriServ/LexUriServ.do?uri $=\mathrm{CO}$ M:2009:0154:FIN:LT:PDF>.

Europos teisès departamentas prie Lietuvos Respublikos teisingumo ministerijos [interaktyvus]. [žiūrèta 2013-08-29]. $<$ http://www.etd.1t/popup2.php?m_news $\mathrm{id}=140 \&$ tmpl_name $=\mathrm{m} \_$news_print_form $>$.

Europos Komisijos pasiūlymas dèl Tarybos reglamento dèl Europos privačios bendrovès statuto. $\mathrm{KOM}(2008) 396$ galutinis [interaktyvus]. [žiūrèta 2013-08-29]. <http:// eur-lex.europa.eu/LexUriServ/LexUriServ. do?uri=COM:2008: 0396:FIN:LT:PDF>.

Gaivenis, V. Notaras šiandienos teisineje sistemoje. Justitia. 1999, 1-6:15.

Gaivenis, V. Nuo raštininko iki notaro. Vilnius: R. Paknio leidykla, 2007. 
Götte, T. Europos Sajungos notariatų tarybos veikla, tarptautinio bendradarbiavimo nauda ir tarybos įnašas stiprinant pagrindinius lotyniškojo notariato principus. Pranešimas perskaitytas $2012 \mathrm{~m}$. gruodžio $1 \mathrm{~d}$. tarptautinèje konferencijoje „Teisè, atsakomybè, patikimumas". Notariatas. 2013, 15.

Generalinio advokato Pedro Cruz Villalon 2010 m. rugsejjo 14 d. išvada [interaktyvus]. [žiūrèta 2013-08-29]. <http://curia.europa.eu/ juris/document/document.jsf?text $=\&$ docid $=$ 78700\& pageInde $x=0 \&$ doclang $=1 \mathrm{t} \&$ mode $=1$ st \&dir $=\&$ occ $=$ first $\&$ part $=1 \& \mathrm{cid}=2023382>$.

Juridinių asmenų registro nuostatai, patvirtinti Lietuvos Respublikos Vyriausybès $2003 \mathrm{~m}$. lapkričio 12 d. nutarimu Nr. 1407. Valstybès žinios. 2003, Nr. 107-4810.

Karpavičienė, J. Lietuvos notariato istorija. Vilnius: R. Paknio leidykla, 2012.

2012 m. liepos 4 d. Europos Parlamento ir Tarybos reglamentas (ES) Nr. 650/2012 dèl jurisdikcijos, taikytinos teisès, teismo sprendimų paveldejjimo klausimais pripažinimo ir vykdymo bei autentiškų dokumentų paveldejimo klausimais prièmimo ir vykdymo bei dèl Europos paveldẻjimo pažymèjimo sukūrimo. [2012] OL L 201.

1976 m. Konvencija dèl išrašų iš civilinès būklès aktų ịrašų išdavimo ịvairiomis kalbomis. Valstybès žinios. 2010, Nr. 8-339.

Lietuvos Respublikos notariato įstatymas. Valstybès žinios.1992, Nr. 28-810.

2012 m. balandžio 19 d. Lietuvos Respublikos notariato istatymo 3, 19, 22, 23 straipsnių pakeitimo ir İstatymo papildymo $19^{1}$ straipsniu isstatymas. Valstybès žinios. 2012. Nr. 50-2444.

Lietuvos Respublikos notariato istatymo 3, 15(1), 22, 23, 36, 56 straipsnių pakeitimo ir papildymo ịstatymas Nr. XI-1916. Valstybès žinios. 2012, Nr.4-114.

Lietuvos Respublikos Vyriausybès nutarimas „Dèl Lietuvos Respublikos Vyriausybès 2003 m. lapkričio 12 d. nutarimo Nr. 1407 „Dèl Juridinių asmenų registro įsteigimo ir juridinių asmenų registro nuostatų patvirti- nimo“" pakeitimo" Nr. 1441. Valstybès žinios. 2009, Nr. 135-5882.

Lietuvos Respublikos Vyriausybės nutarimas Nr. 701 „Dèl Lietuvos Respublikos Vyriausybės $2003 \mathrm{~m}$. lapkričio $12 \mathrm{~d}$. nutarimo Nr. 1407 „Dèl Juridinių asmenų registro įsteigimo ir juridinių asmenų registro nuostatų patvirtinimo" pakeitimo". Valstybès žinios. 2011 , Nr. 75 - 3612.

Lietuvos Respublikos Konstitucinio Teismo 2008 m. sausio 7 d. nutarimas „Dèl Lietuvos Respublikos antstoliu įstatymo 45 straipsnio 3, 5 dalių atitikties Lietuvos Respublikos Konstitucijai“. Valstybès žinios. 2008, Nr. 4-136.

Lietuvos Respublikos Konstitucinio Teismo 2010 m. kovo 22 d. nutarimas „Dèl Lietuvos Respublikos notariato ịstatymo 23 straipsnio 3 dalies (2003 m. sausio $23 \mathrm{~d}$. redakcija) atitikties Lietuvos Respublikos Konstitucijai“. Valstybès žinios. 2010, Nr. 34-1620.

Lietuvos Aukščiausiojo Teismo 2008 m. balandžio 29 d. nutartis civilinèje byloje Nr. 3K3-264/2008.

1994 m. sausio 18 d. Europos Parlamento rezoliucija.

2006 m. kovo 23 d. Europos Parlamento rezoliucija.

Nekrošius, V. Pranešimo, perskaityto Lietuvos notarų rūmų, Koblenco (Vokietija) notarų rūmų ir Nacionalinio muziejaus Lietuvos Didžiosios Kunigaikštystès valdovų rūmų kolokviume „Notariatas ir viešasis interesas“ $2011 \mathrm{~m}$. lapkričio $28 \mathrm{~d}$. Vilniuje tezès. Notariatas. 2012, 13.

Notarų gyventojams teikiamų teisinių paslaugu poreikių vertinimo metodika, patvirtinta Lietuvos Respublikos teisingumo ministro 2006 m. gruodžio 28 d. ịsakymu Nr. 1R-481. Valstybès žinios. 2007, Nr. 2-94.

Report on European judicial systems [interaktyvus]. [žiūrèta 2013-08-29]. <Edition2008//http://wcd.coc.int/ViewDoc. jsp?id=1336209\#p18881_486910>.

Tarptautinès lotyniškojo notariato sajungos (UINL) Europos reikalų komisijos (CAE) 
plenarinés sesijos, vykusios $2010 \mathrm{~m}$. gegužès 21-22 d., medžiaga (nepublikuota).

Sutarties dèl Europos Sajungos veikimo suvestinè redakcija. [2012] OL C 326.

Woschnak, K. Notariatas Europos Sajungoje.

Padètis Europoje: iššūkiai ir profesinès stra- tegijos gairès. Tarptautinès konferencijos, vykusios $2004 \mathrm{~m}$. vasario $12 \mathrm{~d}$., medžiaga. Lietuvos notariato uždaviniai Lietuvos Respublikai tapus Europos Sajungos nare. Lietuvos notarų rūmai, 2004.

\section{NOTARY TOPICALITIES}

\section{Laura Gumuliauskienè, Dalija Svirbutienė}

Mykolas Romeris University, Lithuania

Summary. The article overlooks the topicality of today's notariat - the experience, challenges and perspectives within the context of the Lithuanian law system, taking into account the tendencies of notaries legal regulations in the European Union and the rest of the world. The article also discusses the very controversial request that has reached the Court of Justice of the European Union, regarding the requirement of citizenship for the notary, the diversity of the notary's functions, the conception of e-notary, the increase of notarial services at an international level and the latest initiatives of the European Union in the legal regulation of the activities of notaries.

In 2012, when the independent Notariat of Lithuania celebrated its $20^{\text {th }}$ anniversary, a staggering $86 \%$ of respondents fully trusted in notaries. However, the authority of notaries depends not only on the notaries themselves, but also on other government institutions, officials and politicians.

The goal of the Latin Notariat, a member of which the Lithuanian Notariat has been since 1992, is to spread the main needs of a modern society - legal security, the reduction of judicial measures, transparency, etc.

Through the delegated functions by the states for the notaries, the partnership of the public and private sectors is going through a rebirth. The state should constantly overlook the possibility to transmit new functions to the notaries, as they are authorized persons of the state. This would not only increase the availability of legal services to the society, but also save the budget by helping to terminate unnecessary administrational services with the state.

Special attention and preparations must be appointed to the "cross border notary" system. The ability to act by overstepping legal systems of other states is not only one of the most relevant tasks of the modern notaries, but also a chance for the Notariat to take up an important place in the future society.

One of the necessary assumptions for a successful notary functioning is the transfer of operative and reliable notary actions to the cyberspace. However, by all means e-notary should not mean that the quality and legal reliability of authentic instrument will decrease.

Keywords: notary, Latin notariat, authentic document, notarial deed. 
Laura Gumuliauskienė, Mykolo Romerio universiteto Teisès fakulteto Civilinès justicijos instituto docentè. Mokslinių tyrimų kryptys: tarptautinis ir Europos Sajungos civilinis procesas, užsienio teismų sprendimų ir autentiškų dokumentų pripažinimas ir vykdymas, notariatas.

Laura Gumuliauskienè, Mykolas Romeris University, Faculty of Law, Institute of Civil Justice, Associate Professor. Research interests: International and European civil procedure, recognition and enforcement of foreign judgments and authentic instruments, notariat.

Dalija Svirbutienė, Mykolo Romerio universiteto Teisès fakulteto Civilinės justicijos instituto lektorè. Mokslinių tyrimų kryptys: notariato teisè, šeimos teisè, daiktinè teisè.

Dalija Svirbutienė, Mykolas Romeris University, Faculty of Law, Institute of Civil Justice, Lecturer. Research interests: notariat law, family law, property law. 